\title{
Liberals, Libertarians and Educational Theory
}

\section{Lindsay Paterson}

\section{(2) OpenEdition}

\section{Journals}

Electronic version

URL: http://journals.openedition.org/etudesecossaises/80

ISSN: 1969-6337

\section{Publisher}

UGA Éditions/Université Grenoble Alpes

Printed version

Date of publication: 30 January 2008

Number of pages: 143-158

ISBN: 978-2-84310-110-6

ISSN: 1240-1439

\section{Electronic reference}

Lindsay Paterson, «Liberals, Libertarians and Educational Theory », Études écossaises [Online], 11 |

2008, Online since 30 January 2009, connection on 07 September 2020. URL : http://

journals.openedition.org/etudesecossaises/80

This text was automatically generated on 7 September 2020 .

(c) Études écossaises 


\title{
Liberals, Libertarians and Educational Theory
}

\author{
Lindsay Paterson
}

1 The utopianism of the new right concerning markets certainly has influenced their views about how to organise the governance of education, ever since Milton Friedman's 1955 essay "The role of government in education". But privatisation of the kind that Friedman wanted has rarely in fact been tried, the notable exception being the attempt in Chile under Pinochet, and even there fewer than one half of students were in private schools one decade after the reforms (Friedman, 1955; Ladd, 2002; Hsieh and Urquiola, 2002).

2 So this essay concentrates on a less commonly discussed utopian feature of the new right attitude to education. Student-centred education is usually thought of as a utopia of the left. But it is also, less obviously, a utopia of the right, one which has become remarkably successful in ways that are little acknowledged. Its dominance not only threatens the coherence of anything we might reasonably call an "education", but threatens also the scope for students to acquire from their education the capacity to think critically.

\section{Student-centred Education}

The key ideas may be summed up from John Darling's lucid account (Darling, 1994; Entwistle, 1970). Student-centred education is characterised by:

- an appreciation of children as individuals;

- an awareness of children's growth and development; and children's growth is not to be thought of teleologically, childhood not being a defective version of adulthood;

- the teacher is no more than a "facilitator".

Hence the curriculum is based on freedom, discovery, experience and creativity, as opposed to engaging with a pre-existing body of knowledge to which the teacher is an authoritative and wise guide. 
These ideas came to prominence in the early twentieth century as the state expanded its involvement in education, and their main vehicle was the New Education Fellowship. It embraced many prominent educationalists, including R.H. Tawney, Karl Mannheim, Bertrand Russell, Dora Russell, Jean Piaget, John Dewey, Maria Montessori, and A.S. Neill, who was perhaps the most famous practicising exponent of the ideas. The movement led to the establishment of various "free schools" in the late-nineteenth and early-twentieth centuries, especially in England - for example Abbotsholme, Bedales, Oundle and Beacon Hill (run by the Russells). The most long-lasting and bestknown of these are the Rudolf Steiner schools (Mack, 1971). The intellectual predecessors of this movement include Froebel, Robert Owen, Rousseau, Comenius, Milton, and Francis Bacon. So it is a line of educational thought with a distinguished past, although until recently largely among rebels.

Before we move to the Right's attitudes to these ideas, four comments clarify the specific ways in which they might be described as radical. The first concerns their romanticism. They date ultimately from Rousseau's idea of childhood, indeed his invention of childhood (Numata, 2003). Adults discovered children as different from the late-eighteenth century on, and, influenced by the wider European reaction against rationalism, it came to be believed that metaphors of natural growth were the way in which child development should be understood (Oelkers, 2002). This was believed to be as true on moral as on intellectual grounds. It was romantic also in its radical individualism: for Rousseau society was the source of evil; but it was an individualism of experience, of the senses, rather than of intellect and will. This romantic view attracted much support among intellectuals, especially novelists and poets, for example Tolstoy (for example in the discussion of education in Anna Karenina), Thomas Mann (who sent his son Klaus to the student-centred Odenwaldschule in Hesse (Mann, 1932)), Shaw (for instance in his preface to Misalliance), Wells (Mack, 1971, p. 266-79) and, more ambivalently, D.H. Lawrence (1968).

6 The second comment expands on the importance attached to experience in this theory. Experience replaced any kind of canon as the source of ideas for the curriculum, and, indeed, in the work of Froebel, experience was almost mystically venerated (Oelkers, 2002). A.S. Neill's views on the importance of experience for educational practice are summarised by Darling (1984): all knowledge can and should be related to the experience of the pupil; all knowledge develops in response to a human need to cope with the practical business of living; the divisions between traditional divisions of knowledge (or "disciplines") are artificial; and the things which children learn are less important than the techniques of learning which they acquire. John Dewey said that knowledge is not a heritage to be passed on but something which learners create for themselves (Darling and Nisbet, 2000): knowledge is a continuing reconstruction of experience. In this way Dewey's constructivism relates directly to pragmatist philosophy, and hence to utilitarian conceptions of knowledge; nevertheless, we should note that Dewey's position on student-centredness is complex, as we will see (Carr, 1988).

7 All of these propositions became commonplaces of the student-centred approach. One of the main pedagogical consequences of this attempt to embed learning in experience has been "mastery learning" - learning as pursuing behavioural objectives an approach invented by the psychologist Benjamin Bloom (Postlethwaite and Haggarty, 1998). Teachers have to break down their course into short units; each unit 
has specific objectives; teachers have to plan each unit to take account of pupils' preexisting knowledge and understanding; there has to be a test at the end of each unit; and pupils who do not pass the test - who have not mastered the unit - are directed towards remedial work. We return to some of the more recent consequences of this later.

The third point is about the scientific aspirations of the student-centred project. It was part of a much grander ambition to render pedagogy scientific, in the English-language sense (Walkerdine, 1998). Piaget argued that knowing the laws of mental and moral development enables education to act on nature's ground. If that is so, then teaching becomes observation and recording of natural development. There was also a close involvement with the early versions of psychoanalysis (Jenkins, 2000), the belief that childhood innocence can be maintained only by total surveillance. From this then came the child guidance movement as well as specific pedagogies, and also the importance of working with whole families, in particular with mothers (as allegedly the best-placed person to observe the development of the child). Emerging from that was the sense of elementary teachers as surrogate mothers. This scientific aspiration accounts in part for the popularity of the New Education in the democracies in the 1920s and 1930s: it seemed a rational educational response to the indoctrination and propaganda of the Nazis and the Soviet Union.

The fourth comment is about the suspicion of any kind of schooling and even of teachers that is to be found among the most radical elements of the student-centred tradition (Illich, 1973): these were too formal, too imbued with the dominant ideology, and thus too inclined to prevent the natural growth of the child. That is where, in the less extreme versions of this theory, the idea of the teacher as "facilitator" came from.

In some form, these ideas have had an impact on educational practice throughout the world, especially the developed world. We will return to some of that impact under right-wing regimes shortly, but we should note more generally that the ideas have been picked up almost regardless of the ideological context. The greatest impact has been in the UK, the USA and northern European countries apart from Germany, although there has also been significant impact on early years education in France, Italy and Spain: the guiding philosophy of most policy on school education in these countries, at least since the 1960s, can be summed up in some widely quoted words of the English Hadow report of 1931, which is firmly within the new education paradigm: "the curriculum is to be thought of in terms of activity and experience rather than of knowledge to be acquired and facts to be stored". In these countries, it has become the dominant ideology in the faculties of education of the universities, and hence has deeply shaped the theories and practices of school teachers.

11 What is more, by the mid-twentieth century, student-centred education had become the normal pedagogical ideology of leftist politics throughout Europe, as part of its hostility to hierarchy and tradition. Nearly all the writers mentioned earlier have been liberals, at least in a vague and romantic sense - Neill, Dewey, Mann, Mannheim, Tawney, Shaw, Wells, Tolstoy, Rousseau himself. In particular, this ideology was usually not just of the left but of the anarchist left, becoming a standard part of $1960 \mathrm{~s}$ liberationist ideology. The de-schooling movement and the movement associated with radical psychoanalysis became part of the core of that decade's leftists assumptions. So, for convenience, for the remainder of this essay, I will refer to the assembly of beliefs that I have been describing as "left-anarchist progressivism". 


\section{The Right and Student-centredness} been subjected to stringent critique from the right. The main criticism has been that child-centred education encourages anarchy - a breakdown of discipline in all senses: the fear, as John Wilson puts it, is that when authority arrangements break down, fanaticism is given free rein (Wilson, 1989). The right also objects to the deintellectualisation inherent in an approach that gives such respect to experience: in particular, they believe that not applying the intellect to ethical questions is ultimately disastrous to social stability. R.S. Peters, for example, argues that education is an initiation into activities or modes of thought that are intrinsically worthwhile, and so cannot be thought of merely as experience, and cannot be rediscovered by each learner spontaneously (Peters, 1966). Probably the best-known aphorism from this school of conservative critique of student-centredness is Michael Oakeshott's that education is a conversation between generations (Oakeshott, 1989).

13

Note, however, that these objections are from the conservative right of an old sort, not from the radical right of the kind that has come to power in many places in recent decades. In fact, the right's relationship to student-centred education is more complex and ambivalent than the conservative critique would suggest. The first point to note is that there has always been a strand of support for student-centredness that is located in a quite different ideology from left-anarchism. The most obvious is in a concern of the late-nineteenth and early twentieth centuries with moral regeneration, and a belief that traditional schooling was not adequate to this task (Darling, 1981). For example, Cecil Reddie, founder of Abbotsholme, far from being an anarchist, believed firmly in a natural social hierarchy: for example, his revised version of the fifth Christian commandment read: "they that despise, or treat ill, their parents, guardians or teachers, will suffer dire remorse" (Darling, 1981, p. 18).

One of the best-known of these right-wing progressives was Kurt Hahn, a Jewish refugee from Hitler, who founded the Gordonstoun school in northern Scotland in the 1930s. The regime which he instituted there was aimed at cleansing young men, in stark contrast, for example, to the sexual liberation of A.S. Neill's Summerhill. Gordonstoun was favoured by members of the British royal family, including the queen's husband: it then led also to the Duke of Edinburgh Award, which still today tries to extend the same muscular development of a moral personality to adolescents more generally.

What appealed to such thinkers was the emphasis on experience, on moral training, and on preparation for responsible citizenship. The new education seemed to them a welcome counter to what they alleged was the excessively theoretical curriculum of the secondary schooling that was emerging properly in most European countries at that time, and a counter also to the rote-learning that had characterised elementary education in the middle of the nineteenth century.

Moreover, this authoritarian progressivism was not confined to schooling: it appealed strongly also to the nascent Boy Scouts movement of the years around the First World War, under the leadership of Robert Baden-Powell, and slightly later the Girl Guides (Warren, 1986). The Scouting philosophy placed a great deal of emphasis on experiential learning - for example, nature study and woodcraft. It sought to train

Études écossaises, 11 | 2008 
young people's character for citizenship, self-reliance, self-improvement and public service. It had a heavy emphasis on spiritual development. It was in fact firmly opposed to militarism, and Baden-Powell refused to allow the Scouts in Britain to be used for military training during the War; that anti-militarism was part of its support for selfreliance etc. But it was equally strongly opposed to socialism in any form. It was, in short, a non-socialist form of collectivism, anti-individualist, not even potentially or theoretically about freedom.

Once we see this right-wing version of student-centredness, and how it used experiential learning in a thoroughly anti-intellectual way, we might be less surprised to discover a Fascist version too (Entwistle, 1979). In fact, one of the earliest attempts to reform a whole public-school system on child-centred lines was by Mussolini's first Minister of Public Instruction, Giovanni Gentile. The reform was managed by the director-general of elementary education, Lombardo-Radice, a former socialist. Mussolini described this reform as "the most fascist of all the fascist reforms". The purpose was to liberate the schools from the teaching of facts. Religious instruction became compulsory, in the interests of promoting the spiritual development of the child. The examination system was reformed to test "creativity" rather than factual knowledge. And the whole was rigorously meritocratic: at the end of elementary school, students were tested for entry to secondary school or vocational school.

The reforms were praised as positive, vigorous and creative in many countries: we have to recall that, to much mainstream opinion, "fascist" in the early 1920s had an aura of "progressive" or "modern" (Oelkers, 2002). The education reforms, in particular, helped to reinforce the sense in Italy that fascism was a liberation movement. Antonio Gramsci was not among the enthusiasts, and we can anticipate a later stage in the argument by noting that he predicted that child-centred progressivism would be friendly to political authoritarianism, the veneration of experience and the denigration of the intellect underpinning fascism's denial of reason and its dependence on intoxicating pageantry: indulging in activity for activity's sake. Gramsci's analysis points to the ambiguity in this fascist legacy of the status of the individual: apparently celebrating the individual, it actually subsumes the individual into the collective.

Now, we might be tempted to regard all these early twentieth century instances of right-wing support for progressivism as quaint, superseded by the left-anarchist trajectory that came to dominate after the 1940s. But the next step in the argument is that, in important respects, the right-wing veneration of experiential learning has now come to dominate educational policy. We can label this vocational progressivism because it has its origins in the belief that the main purpose of education is to prepare people to be efficient workers. It is based ultimately on the utopian belief that human beings could develop an unfettered mode of existence in which the intellect did not interfere with direct experience, that old romantic idea that what was wrong with European civilisation was the Aristotelian split between body and mind.

In fact, the tenets of student-centredness entered vocational education early, in the various attempts in the 1930s to use education to get unemployed young people into work. It survived as a current in thinking about vocational education in the post-war period. But the full flowering did not come till the 1970s, and has continued to the present. In the 1980s the philosophy of vocational education became student-centred, with an emphasis on students' discovering things for themselves, and with a hostility to any kind of theory (Hartley, 1987, 2003). This accompanied a rejection of old styles of 
apprenticeship, and a rejection of old ideas about "crafts": the efficient worker had to be flexible, and so what was required was competence in specific skills, not the induction into a craft. That kind of worker is more readily managed than a craftsman who has a stable identity from which individual autonomy might spring. In one sense that is what Marx, Hegel and Adam Smith were writing about in their concept of alienation: the separation of measurable capacities from the worker's identity.

More recently, this ideology has fitted well with fashionable rhetoric about the nature of the economy, requiring flexible specialisation, the economy allegedly requiring generic workers. Writers such as Zygmunt Bauman argue, further, that work is increasingly governed by aesthetic criteria rather than by abstract theory. It is suggested that this new economy and the new education preparing for it are associated with the rise to power of a new professional class - software engineers, design specialists, media workers, purveyors of personal finance - no longer gaining its authority from hierarchy and accepted classifications of knowledge, but now much more dependent on flexible careers, more interested in "identities" and "lifestyles" than status, and more inclined to see education as being about a sort of playful experimentation than about disciplined learning (Power et al, 2003). This idea about a new professional class comes ultimately from Basil Bernstein, who defined the new middle class as those concerned with the symbolic ordering of society (Bernstein, 1975). David Hartley points out that the language used here is remarkably close to the language used by the progressive educationists to promote experience, creativity, and spontaneity in schooling. He also points out that the same language can be used to celebrate consumerism, and indeed Paul Standish makes the link to Lasch's culture of narcissism (Standish, 1997).

The argument is, then, that the ideas of student-centred education entered vocational education as part of a new way of inducting people into work: flexible competence rather than socialisation into a craft identity. The more thorough argument is then that this movement, having started in the lower-status parts of vocational education, has now spread to embrace almost all education. School and university curricula have been reconstructed in the last twenty years to follow the same ideology. Following the ideas of "mastery learning", the syllabus has been decomposed into units, which are separately assessed, often with no or minimal holistic assessment at the end of a course. The student is as free as possible to assemble her or his own collection of units, because "disciplines" are regarded as out-dated and alienating. There has been a gradual erosion of the role of theory and of abstract knowledge, and a growth of activity learning, experiential learning, "emotional intelligence", learning that is "relevant" to the life of the learner. There has grown also the belief that students have to be motivated all the time - that deferred gratification is not any longer a sufficient rationale for study (and almost unfettered choice is part of this). And the outcomes of all this are increasingly seen as the preparation of infinitely flexible workers for the "knowledge economy". There is even a new version of the "de-schooling" movement, in which the future is imagined to be free of educational institutions: they would be replaced by the internet etc, and teachers would become "learning consultants" (Bentley, 1998).

23 That is not to say that everything has changed, and that nothing of older models of learning survives. But the re-modelling of education on experiential lines has gone very far indeed. My main proposition is then that this has resulted from a progressivism of 
the right, drawing upon the main tenets of student-centred utopianism to impose its own utopia of experience, first of all on vocational education and, in the last two decades, on the whole of education.

\section{Critique} of contact between it and left-anarchist progressivism. In the UK, the most notable exponent of that left-anarchist view is Stephen Ball, professor of education at King's College in London, and highly influential on academic debates about education in the UK (Ball, 1990; Brehony, 1992, 1997). In the 1980s, Ball argued that the main educational enemy of the left was what he called the "cultural restorationists" or - following Raymond Williams - "old humanists", who would roughly correspond to the conservative critics of progressive pedagogy mentioned earlier. Ball then welcomed the sympathy which many larger employers showed for the vocational progressivism, and saw this as a way of reviving left-anarchist progressivism and of radically reconstructing schooling whether vocational or not: typical of his comments are that "vocational progressivism" is "set over against the elitist conceptions of knowledge proselytised by the old humanists".

Ball's view is now the dominant one on the left, and so the left has no developed basis for offering a critique of the current reconstruction of the curriculum. It seems to be rather meekly accepting that because current reforms are couched in terms of "freedom" and "flexibility", then they must be welcome to the left; and the left also seem to have accepted that the only kind of education that can prepare people for work is the kind that has been put in place in the past two decades, with its rejection of theory and its celebration of flexibility spontaneity.

might do well, then, to return to what Gramsci had to say about Mussolini's reforms: "the struggle against capital", he wrote, requires that "knowing' [...] supersedes 'spontaneity", giving "the worker the understanding of the conditions in which he struggles, of the fundamental tendencies which operate in the system of relationships, of the processes of development which society undergoes to sustain within itself irreducible antagonisms" (Entwistle, 1979). Understanding all this requires propositional knowledge, embedded in theories and emerging out of a tradition of intellectual engagement.

So we can summarise a left critique of progressivism under five headings:

\section{Spontaneity is not enough}

John Dewey, having doubts about the most radical versions of experiential learning, acknowledged that children cannot develop truth out of their own minds (Dewey, 1902): "nothing can be developed from nothing, nothing but the crude can be developed out of the crude, and this is surely what happens when we throw the child back upon his achieved self as a finality". Any education worthy of the name requires students to engage with the unfamiliar, the "not relevant". Related to this is the celebration of emotion over reason, which is dangerous to thought in many more mundane ways than Gramsci observed from the Italian fascists. It has been argued, in fact, that basing an educational philosophy on the experience of students replaces the 
authoritarianism of the teacher with the authoritarianism of the learner, who becomes the only arbiter of what is worth knowing (Walter, 1996). So this first element of the left critique of progressivism is an educational instance of the general left critique of the romantic naivety of what has been called 1960s radicalism (including existentialism).

\section{Social control}

The second element of the critique is that the new right's final endorsement of studentcentredness tends to confirm Walkerdine's point that this form of pedagogy offers a convenient kind of social control: as with utopian criminology, the classification of stages of development, etc., came to be closely linked to regulation of development. Sharp and Green described progressive teaching, like social work, as a means of socialising people through "soft psychological technology" (Sharp and Green, 1975). It manages aspirations by legitimising a wider range of "learning styles" and hence of assessments: "modern child-centred education is an aspect of romantic radical conservatism which involves an emotional turning away from society". In Basil Bernstein's terms, it is an "invisible" form of control, in contrast to explicit, hierarchical kinds. So, despite the rhetoric of individuality, this pedagogy is actually opposed to the development of any coherent and stable kind of individual autonomy. It is not aimed at developing or shaping autonomous individuals, but at the manipulation of experience by means of measurable outcomes.

\section{Learning as social}

30 The romantic individualism of student-centredness ignores the intrinsically social character of worthwhile learning - the extent to which learning has to be an initiation into a community of knowledge, even when Oakeshott's "conversation" becomes more like an argument (a point which, it should be said, he acknowledges). The best-known exponent of this idea is Lev Semenovich Vygotsky (1896-1934), who proposed the importance of formal learning for any advanced understanding (Gee, 1996).

This point is not so much prescriptive as descriptive. As a matter of fact the children of the bourgeoisie will be socialised through their families into forms of knowledge that will give them power (as Pierre Bourdieu repeatedly argued). So not to teach explicitly, and to rely on knowledge developing spontaneously through experience, would be merely to further privilege those who are already privileged. Again, studentcentredness is only superficially individualistic. Because it abstracts the individual from social relations, student-centredness has no conception of how to educate the individual into a critical relationship to a tradition. By thus allowing the learner to be ignorant of structural impediments to learning, student-centredness actually negates individual autonomy.

\section{Understanding society}

The fourth element notes that it is really not surprising that progressivism has become the dominant educational ideology because, following Gramsci, it seems clear that understanding social development requires facts, theory and knowledge. Being truly free 
requires a capacity to recognise the threats to freedom, and also an understanding of what kinds of human activity are possible. That requires knowledge of cultural variety, and of social change. The current vogue for students' learning how to be flexible workers etc. because society is changing so rapidly has nothing to say about how society ought to change: the learner is not provided with a secure centre of identity from which a critique of social change (or anything else) could emerge.

In this element of the critique, we can give particular attention to the critique of "deschooling". Herbert Gintis noted long ago (Gintis, 1972) that Ivan Illich celebrates the small-scale entrepreneur, the person who has become the hero of current political writing about flexible specialisation. Gintis also predicted that if anything like Illich's de-schooled Utopia came about, it would serve merely a utilitarian and individualistic conception of humanity: "a commodity-fetishist cafeteria-smorgasbord ideal of education". That excoriation seems remarkably prescient of the long-term consequences of "mastery learning", in the burgeoning catalogues of "learning modules" which issue from almost all educational institutions today.

\section{Freedom achieved through education}

The final element of the critique is a more general version of the fourth. Knowledge and understanding are pre-requisites of freedom, and so freedom is achieved through education, not necessarily within it. That process might be difficult, might defer gratification, and might require engagement with the thought and style of others: but the key point is that the process is de-centred. Ken Jones put this well at the height of Thatcherism in the UK, accepting as long ago as 1983 that it was not enough for the left to defend 1960s progressivism: "an education that substitutes for knowledge of nature and society a programme of socialisation and self-realisation of the entirely nugatory sort [...] is incorrectly founded."

Student-centred education is best known as a utopia of the left, specifically of leftanarchism. I have argued in this essay that it should also be understood as a utopia of the right, in its veneration of experience over propositional knowledge, in its celebration of the emotions over reason, and in its encouragement of spontaneity over intelligent activism. It is utopian insofar as it imagines a human being unencumbered by an intellect, whose will is spontaneously regulated by accumulated experience, and whose relations with others are unmediated by rational calculation, or by any coherent and stable identity.

In important respects, this utopianism of the right has become one of the right's most successful hegemonic projects in the past two decades, more insidious, more insistent, and more successful in meeting its own aims than any of the attempts at educational privatisation. This change is little-noticed but now pervading education in many countries at all levels, in its fragmentation of the curriculum into modular units, in its precise specification of learning outcomes as the behavioural consequences of these modules, in its promotion of student choice over engagement with a canon, and in its systematic denial of the importance of theory.

The right has achieved this partly as utopian ideology but mainly as economics. It has successfully established in public debate that the nature of the economy requires this kind of flexible specialisation. And the left has been largely powerless to resist because it has mistaken this right-anarchism for liberation, and has forgotten that spontaneity 
and experience are no substitute for the development of secure identity through rational, voluntary immersion in a community of learning.

\section{BIBLIOGRAPHY}

BALL S., Politics and Policy Making in Education, London, Routledge, 1990.

BENTLEY T., Learning Beyond the Classroom, London, Routledge, 1998.

BERNSTEIN B., "Class and pedagogies: visible and invisible" in Class, Codes and Control, vol. 3, London, RKP, 1975.

BREHONY K.J., “What's left of progressive primary education?" in Rattansi A. and Reeder D. (eds.), Re-thinking Radical Education, London, Lawrence and Wishart, 1992, p. 196-221.

-, “An 'undeniable' and 'disastrous' influence? Dewey and English education (1895-1939)”, Oxford Review of Education, 23, 1997, p. 427-445.

CARR D., "Knowledge and curriculum: four dogmas of child-centred education", Journal of Philosophy of Education, 22, 1988, p. 151-162.

DARLING J., "New life and new education: the philosophies of Davidson Reddie and Hahn", Scottish Educational Review, 13, 1981, p. 12-24.

-, “A. S. Neill on knowledge and learning”, British Journal of Educational Studies, 32, 1984, p. 158-171.

-, Child-Centred Education and its Critics, London, Paul Chapman, 1994.

DARLING J. and NISBET J., “Dewey in Britain”, Studies in Philosophy and Education, 19, 2000, p. 39-52.

DEWEY J., The Child and the Curriculum, Chicago, University of Chicago Press, 1902.

ENTWISTLE H., Child-Centred Education, London, Methuen, 1970.

-, Antonio Gramsci: Conservative Schooling for Radical Politics, London, Routledge and Kegan Paul, 1979.

FRIEDMAN M., "The role of government in education" in Solo R.A. (ed.), Economics and the Public Interest, New Jersey, Rutgers University Press, 1955.

GEE J.P., "Vygotsky and current debates in education: some dilemmas as afterthoughts to Discourse, Learning and Schooling", in Hicks D. (ed.), Discourse, Learning and Schooling, Cambridge, Cambridge University Press, 1996, p. 269-282.

GINTIS H., "Towards a political economy of education: a radical critique of Ivan Illich's Deschooling Society", Harvard Educational Review, 42, 1972, p. 70-96.

HARTLEY D., "The convergence of student-centred pedagogy in primary and further education in Scotland: 1965-1985”, British Journal of Educational Studies, 1987, p. 115-128.

-, “New economy, new pedagogy?", Oxford Review of Education, 29, 2003, p. 81-94. 
HSIEH C.-T. and URQUIOLA M., "When schools compete, how do they compete?", occasional paper

43, National Center for the Study of Privatisation in Education, Teachers College, Columbia University, 2002.

ILLICH I., Deschooling Society, Harmondsworth, Penguin, 1973.

JENKINS C., "New education and its emancipatory interests (1920-1950)", History of Education, 29, 2000, p. 139-151.

JONES K., Beyond Progressive Education, London, Macmillan, 1983.

LADD H., "School vouchers: a critical view", Journal of Economic Perspectives, 16 (4), 2002, p. 3-24.

LAWRENCE D.H., “Education of the people”, in Phoenix, London, Heinemann, 1968, p. 587-665.

MACK E.C., Public Schools and British Opinion Since 1860, Westport, Greenwood, 1971.

MANN K., Kind Dieser Zeit, Berlin, Transmare, 1932.

NUMATA H., "What children have lost by the modernisation of education: a comparison of experiences in western Europe and eastern Asia", International Review of Education, 49, 2003, p. 241-264.

OAKESHOTT M., Michael Oakeshott on Education, Fuller T. (ed.), New Haven, Yale University Press, 1989.

OELKERS J., "Rousseau and the image of 'modern education' ", Journal of Curriculum Studies, 34, 2002, p. 679-698.

PETERS R.S., Ethics and Education, London, George Allen and Unwin, 1966.

POSTLETHWAITE K. and HAGGARTY L., "Towards effective and transferable learning in secondary school: development of an approach based on mastery learning", British Educational Research Journal, 24, 1998, p. 333-353.

POWER S., EDWARDS T., WHITTY G. and Wigfall V., Education and the Middle Class, Buckingham, Open University Press, 2003.

SHARP R. and GREEN A., Education and Social Control, London, RKP, 1975.

STANDISH P., "Heidegger and the technology of further education", Journal of Philosophy of Education, 31, 1997, p. 439-459.

WALKERDINE V., "Developmental psychology and the childcentred pedagogy: the insertion of Piaget into early education" in Henriques J. (ed.), Changing the Subject, London, Routledge, 1998, p. 153-202.

WALTER S., “The 'flawed parent': a reconsideration of Rousseau's 'Emile' and its significance for radical education in the United States", British Journal of Educational Studies, 44, 1996, p. 260-274. WARREN A., "Sir Robert Baden-Powell, the Scout Movement and Citizen Training in Great Britain, 1900-1920", English Historical Review, 101, 1986, p. 376-398.

WILSON J., "De-intellectualisation and authority in education", Oxford Review of Education, 15, 1989, p. 111-119. 
AUTHOR

LINDSAY PATERSON

Edinburgh University 